\title{
Impact of gene polymorphism of glutathione S-transferase and ghrelin as a risk factor in Egyptian women with gestational diabetes mellitus
}

\author{
Mai M. Madkour ${ }^{*}$, Afaf M. El-Said² ${ }^{2}$ Abd El-Aziz A. El-Refaey ${ }^{3}$, Abd El-Aziz F. Abd El-Aziz ${ }^{1}$ and \\ Fardous F. El-Senduny ${ }^{1}$ (D)
}

\begin{abstract}
Background: Gestational diabetes mellitus is the most common metabolic dysfunction that arises during pregnancy. GDM can lead to serious health complications for both the mother during pregnancy and after the delivery of the baby. Additionally, mother-offspring suffers from abnormalities in metabolism. The study aimed to investigate glutathione S-transferase P1 and ghrelin genetic variants in pregnant women diagnosed with gestational diabetes using a tetra-primer amplification refractory mutation system.

Results: This study demonstrated that the frequencies of genotypes in women with GDM were GSTP1-AG (87.1\%) and GHRL-GG (100\%). The study revealed no significant differences in the frequency of either genotype or allele of both GSTP1 and ghrelin between GDM and healthy pregnant women.

Conclusions: This study may be the first study designed to demonstrate that there is no association between the genotype and allele frequencies of GSTP1 (rs1695) and ghrelin (rs696217) in the development of gestational diabetes mellitus in Egyptian women.
\end{abstract}

Keywords: Gestational diabetes, Glutathione S-transferase P1 gene, Ghrelin gene, Genetic polymorphism, Lipid profile

\section{Background}

Gestational diabetes mellitus (GDM) is the most common metabolic dysfunction of pregnant women detected in the second or third trimester of pregnancy. In recent decades, GDM has been identified in 35\% of pregnant women throughout the world [1]. GDM can cause hyperglycemia, macrosomia, high blood pressure, preeclampsia, premature birth, and stillbirth at the end of pregnancy [2]. It is not caused by a lack of insulin but by

\footnotetext{
*Correspondence: maimadkour211@mans.edu.eg

1 Biochemistry Division, Department of Chemistry, Faculty of Science,

Mansoura University, Mansoura, Egypt

Full list of author information is available at the end of the article
}

partially blocking the effect of insulin (known as insulin resistance) by various other hormones produced by the placenta, including steroid hormones (progesterone, estradiol, and cortisol) and peptide placental hormone (human chorionic somatomammotropin (HCS) [3, 4]. Insulin resistance leads to metabolic disorders causing dyslipidemia such as high levels of total cholesterol, triglycerides, LDL-cholesterol, and low levels of HDLcholesterol. However, hyperlipidemia is a hallmark of the second half of pregnancy to improve fetal growth [5].

Glutathione S-transferase P1 (GSTP1) gene maps on the long arm of chromosome 11, which is composed of seven exons. In humans, GSTP1 exists as a dimer of identical subunits where each subunit contains 210 
amino acid residues and two binding sites [6]. GSTP1 polymorphism (rs1695) is distinguished by an adenine to guanine substitution leading to isoleucine (Ile) to valine (Val) exchange at position 105 of the coding region [7]. The glutathione S-transferases (GSTs) are isoenzyme superfamilies that detoxify toxic substances and protect macromolecules from reactive electrophiles, reactive oxygen species, chemotherapeutic agents, and environmental carcinogens [8].

The short arm of chromosome 3 (3p25-26) contains the sequence for the ghrelin (GHRL) gene. GHRL is composed of four exons encoding a precursor of preproghrelin (117-aa) [9]. Ghrelin polymorphism (rs696217) is distinguished by guanine to thymine substitution leading to leucine (Leu) to methionine (Met) exchange at position 72 in exon 2 [10]. Ghrelin is secreted by enteroendocrine cells in the stomach and binds to its growth hormone secretagogue receptor (GHSR) [11]. Ghrelin regulates the growth hormone secretion from primary pituitary cells via modulating intracellular calcium levels. Additionally, ghrelin plays a role in glucose metabolism. Thus, ghrelin is a key regulator of energy homeostasis [12].

The study aimed to evaluate the single nucleotide polymorphisms (SNPs) in glutathione S-transferase P1 (A/G rs1695) and ghrelin (G/T rs696217) and correlate its genotyping to gestational diabetes mellitus. This may be the first study designed to reveal that there is no association between the genotype and allele frequencies of both GSTP1 (rs1695) and ghrelin (rs696217) in the development of gestational diabetes mellitus in Egyptian women.

\section{Methods}

This cross-sectional comparative study evaluated women with GDM according to the ethical standards of the Institutional Research Board, Faculty of Medicine, Mansoura University. Informed consent was taken from each participant. One hundred forty pregnant women (seventy women with GDM and seventy healthy women) with a singleton pregnancy were recruited from the Obstetrics and Gynecology Department, Faculty of Medicine, Mansoura University in the period from July 2017 to March 2019.

All participants were at least 18 years of age and were diagnosed with gestational diabetes at $>24$-weeks gestation. Pregnant women with type 1 diabetes mellitus, early macrosomia (baby with a birth weight more than $4000 \mathrm{~g}$ ), polycystic ovary syndrome, or other associated serious medical disorders (hypertension, renal disease, moderate to severe anemia, thyroid disorder, etc.) interfering with maternal and perinatal outcomes were excluded.
Table 1 Primers used in T-ARMS-PCR of glutathione S-transferase P1 gene (A/G rs1695)

\begin{tabular}{lll}
\hline Primer & Sequence $\left(\mathbf{5}^{\prime} \mathbf{-} \mathbf{3}^{\prime}\right)$ & Fragment size \\
\hline FOP & CAGGTGTCA GGTGAGCTCTGAGCA CC & $\begin{array}{l}\text { A allele 233 bp } \\
(\text { FIP + ROP) }\end{array}$ \\
ROP & ATAAGGGTG CAGGTTGTGTCTTGTCCC & $\begin{array}{l}\text { Gallele 290 bp } \\
(\text { FOP + RIP) }\end{array}$ \\
FIP & CGTGGAGGACCTCCGCTGCAAATCCA & Two outer primers 467 \\
RIP & GCTCACATAGTTGGTGTAGATGAGGGA & \\
& IAC & \\
\hline
\end{tabular}

FOR forward outer primer, ROP reverse outer primer, FIR forward inner primer, RIPreverse inner primer

${ }^{a}$ The mismatches of the allele-specific primers are emphasized in bold and underlined

Table 2 Primers used in T-ARMS-PCR of ghrelin gene $(G / T$ rs696217)

\begin{tabular}{|c|c|c|}
\hline Primer & Sequence $\left(5^{\prime}-3^{\prime}\right)$ & Fragment size \\
\hline FOP & GGGGATTTTTTTTTTTTATGGGTTGGTGG & $\begin{array}{l}\text { G allele } 197 \mathrm{bp} \\
(\mathrm{FIP}+\mathrm{ROP})\end{array}$ \\
\hline ROP & $\begin{array}{l}\text { GGAGGACATTGAGGCAGTAGAGCA } \\
\text { GTTG }\end{array}$ & $\begin{array}{l}\text { T allele } 266 \\
\text { bp (FOP + RIP) }\end{array}$ \\
\hline FIP & $\begin{array}{l}\text { GTGGGTTGGTGGTGAGATGTTTACCAA } \\
\text { IAG }\end{array}$ & Two outer primer 407 \\
\hline RIP & GTGGACATGAGGGACAAAGTACC드A & \\
\hline
\end{tabular}

FOR forward outer primer, ROP reverse outer primer, FIR forward inner primer, $R I P$ reverse inner primer

${ }^{a}$ The mismatches of the allele-specific primers are emphasized in bold and underlined

\section{Sample collection and DNA extraction}

Venous blood samples were taken from each patient and dispensed in an EDTA-containing tube. The blood sample was separated into two portions $(3 \mathrm{ml}$ and $2 \mathrm{ml})$. The first portion phase was used to collect plasma after centrifugation at $>2000 \times g$ for $10 \mathrm{~min}$. The separated plasma was used in the investigation of the biochemical analysis. The second portion was used for DNA extraction. DNA was separated using a DNA extraction kit (ABIOpure ${ }^{\mathrm{TM}}$ Genomic DNA, Cat. No. M501DP). All samples showed bands, which represent the genomic DNA when gel electrophoresis was applied. The DNA quantity and quality were measured by reading the absorbance at $\lambda_{230 \mathrm{~nm}}$ and $\lambda_{260 \mathrm{~nm}}$ by Thermo Scientific ${ }^{\mathrm{TM}}$ NanoDrop.

\section{Tetra-primer amplification refractory mutation system (T-ARMS-PCR) analysis PCR analysis for glutathione S-transferase P1 gene}

The primers used in this study (FOP, FIP, ROP, and RIP) are provided in Tables 1 and 2. GSTP1 gene (A/G rs1695) primers were designed by Primer3 software, while ghrelin 
gene (G/T rs696217) primers were designed by using http://www.primer1.soton.ac.uk/primer1.html. Polymerase chain reaction (PCR) was performed in a $20 \mu \mathrm{L}$ volume involving $200 \mathrm{ng}$ of genomic DNA, $3 \mu \mathrm{L}$ of $\mathrm{G}$ allele primers (FOP and RIP) or A allele primers (FOP and RIP) (Table 1), and $10 \mu \mathrm{L} 2 \times$ Taq Master Mix (EmeraldAmp ${ }^{\circledR}$ GT PCR Master Mix-Code No. RR310A). The PCR protocol was as follows: $94{ }^{\circ} \mathrm{C}$ for $5 \mathrm{~min}$, followed by 35 cycles at $94{ }^{\circ} \mathrm{C}$ for $2 \mathrm{~min}$, annealing at $59{ }^{\circ} \mathrm{C}$ for $1 \mathrm{~min}$, and extension at $72{ }^{\circ} \mathrm{C}$ for 1 min with a final extension at $72{ }^{\circ} \mathrm{C}$ for $10 \mathrm{~min}$. The agarose gel electrophoresis (2\%) was performed at $125 \mathrm{~V}$ and a $100 \mathrm{bp}$ MaestroGen DNA ladder (Cat. No.02001_500) was used to investigate and confirm the quality of the PCR products (Cleaver Scientific Ltd, UK).

\section{PCR analysis for ghrelin gene}

The polymerase chain reaction (PCR) was performed in a $25 \mu \mathrm{L}$ volume involving $200 \mathrm{ng}$ of genomic DNA, $1 \mu \mathrm{L}$ of $\mathrm{T}$ allele primers (FOP and RIP) or G allele primers (FIP and ROP) (Table 2), $12.5 \mu \mathrm{L} 2 \times$ Taq Master Mix (EmeraldAmp ${ }^{\circledR}$ GT PCR Master Mix, Cat. No. RR310A), and 4.5 $\mu \mathrm{L} \mathrm{H}_{2} \mathrm{O}$. The PCR protocol was as follows: $95{ }^{\circ} \mathrm{C}$ for $3 \mathrm{~min}$, followed by 35 cycles at $95{ }^{\circ} \mathrm{C}$ for $30 \mathrm{~s}$, annealing at $60{ }^{\circ} \mathrm{C}$ for $30 \mathrm{~s}$, and extension at $72{ }^{\circ} \mathrm{C}$ for $1 \mathrm{~min}$, and $30 \mathrm{~s}$ with a final extension at $72{ }^{\circ} \mathrm{C}$ for $10 \mathrm{~min}$. The agarose gel electrophoresis (2\%) was performed at $125 \mathrm{~V}$ and a 100 bp MaestroGen DNA ladder (Cat. No. 02001_500) was used to investigate and confirm the quality of the PCR products (Cleaver Scientific Ltd, UK).

\section{Biochemical measurements}

The plasma lipid profile was assayed following the kit's instructions by Biodiagnostic (Cairo, Egypt). Plasma levels of total lipids, total cholesterol, triglycerides, and HDL cholesterol can be determined according to the methods of Zollner and Kirsch [13], Richmond [14], Fassati and Prencipe [15], and Burstein et al. [16] respectively. Plasma levels of LDL-cholesterol and VLDL-cholesterol were calculated by the Friedewald equation where VLDL equals triglycerides divided by 5 [17]:

$$
\begin{aligned}
\text { LDL Cholesterol }= & \text { Total Cholesterol } \\
& -(\text { HDL Cholesterol }+ \text { VLDL Cholesterol })
\end{aligned}
$$

\section{Statistical analysis}

Statistical analysis was done using the software package, SPSS version 22, and Excel Software. The data were expressed as mean $\pm \mathrm{SD}$. One-way ANOVA was used for determining the significant difference between women with gestational diabetes and healthy pregnant women. $P$ values $<0.05$ were statistically significant. The frequencies of either genotype or allele of GSTP1 polymorphism between two groups were analyzed by the Fisher exact test and Hardy-Weinberg equilibrium.

\section{Results}

\section{Biochemical investigation of studied groups}

Table 3 showed the demographic characteristics of pregnant women between the two groups. The data found that there was no significant difference in the mean age and body mass index (BMI) among women with gestational diabetes and healthy pregnant women.

The level of insulin resistance was higher in the gestational diabetes group with a significant difference compared with the control group. Total lipids, total cholesterol, triglycerides, LDL-cholesterol, and VLDLcholesterol levels were significantly higher, whereas HDLcholesterol levels were significantly lower in women with GDM than healthy pregnant women (Table 4).

\section{Genetic polymorphism and genotype frequencies Genotype analysis of GSTP1 gene}

The genetic polymorphisms in the GSTP1 gene were investigated and the genotypes were shown in Fig. 1. The frequencies of the genotype of the GSTP1 gene (rs1695) between women with gestational diabetes and healthy pregnant women were listed in Table 5. The distribution of genotypes of GSTP1 for both groups was in alignment with the Hardy_Weinberg equilibrium, which was analyzed by Fisher's exact test (Table 6).

The major risk of gestational diabetes mellitus was evaluated by the codominant, dominant, recessive, and overdominant models as shown in Table 7. In the codominant model (AA vs AG vs GG), there was no significant risk of GDM (OR 2.40, 95\% CI 0.38-14.88, $P=0.342$ ) with the $\mathrm{A} / \mathrm{G}$ and $\mathrm{G} / \mathrm{G}$ genotypes compared with the AA genotype. The dominant model did not show any significant

Table 3 Demographic characteristics of the involved subjects in this study

\begin{tabular}{lllll}
\hline Parameters & GDM group $(\boldsymbol{n}=\mathbf{7 0})$ & Control group $(\boldsymbol{n}=\mathbf{7 0})$ & OR $(\mathbf{9 5} \% \mathrm{Cl})$ & $\boldsymbol{P}$ value \\
\hline Age $($ years $)$ Mean $\pm \mathrm{SD}$ & $28.30 \pm 4.68$ & $27.73 \pm 3.34$ & $1.0(0.944-1.06)$ & 0.407 \\
$\mathrm{BMI}\left(\mathrm{kg} / \mathrm{m}^{2}\right)$ Mean $\pm \mathrm{SD}$ & $26.30 \pm 2.12$ & $25.73 \pm 2.07$ & $1.14(0.89-1.28)$ & 0.109 \\
\hline
\end{tabular}

The data was presented as a mean and standard deviation

OR odds ratio, $95 \% \mathrm{Cl} 95 \%$ confidence interval for the difference between the means for both groups, GDM gestational diabetes mellitus. $P$ is significant when ` 0.05 
Table 4 Comparison of insulin resistance and lipid profile of gestational diabetes mellitus in pregnant women with healthy pregnant women

\begin{tabular}{|c|c|c|c|c|}
\hline Parameters & GDM group $(n=70)$ & Control group $(n=70)$ & OR $(95 \% \mathrm{Cl})$ & $P$ value \\
\hline $\begin{array}{l}\text { Insulin resistance } \\
\text { Mean } \pm \text { SD }\end{array}$ & $24.20 \pm 6.76$ & $7.42 \pm 2.66$ & undefined & $<0.001$ \\
\hline $\begin{array}{l}\text { Total lipids (mg/dL) } \\
\text { Mean } \pm S D\end{array}$ & $1145.60 \pm 171.20$ & $605.32 \pm 155.50$ & $1.02(1.01-1.03)$ & $<0.001$ \\
\hline $\begin{array}{l}\text { Total cholesterol (mg/dL) } \\
\text { Mean } \pm \text { SD }\end{array}$ & $229.11 \pm 34.78$ & $150.03 \pm 22.95$ & $1.127(1.09-1.17)$ & $<0.001$ \\
\hline $\begin{array}{l}\text { Triglycerides (mg/dL) } \\
\text { Mean } \pm \mathrm{SD}\end{array}$ & $299.25 \pm 53.55$ & $140.31 \pm 32.26$ & 5.25 (undefined) & $<0.001$ \\
\hline $\begin{array}{l}\text { LDL-cholesterol (mg/dL) } \\
\text { Mean } \pm \text { SD }\end{array}$ & $142.0 \pm 32.69$ & $76.53 \pm 18.05$ & $1.16(1.12-1.23)$ & $<0.001$ \\
\hline $\begin{array}{l}\text { VLDL-cholesterol (mg/dL) } \\
\text { Mean } \pm S D\end{array}$ & $60.0 \pm 11.45$ & $29.06 \pm 7.05$ & undefined & $<0.001$ \\
\hline $\begin{array}{l}\text { HDL-cholesterol (mg/dL) } \\
\text { Mean } \pm \text { SD }\end{array}$ & $25.37 \pm 6.09$ & $51.45 \pm 6.60$ & undefined & $<0.001$ \\
\hline
\end{tabular}

The data was presented as a mean and standard deviation

OR odds ratio, $95 \%$ Cl 95\% confidence interval for the difference between the means for both groups, GDM gestational diabetes mellitus. $P$ is significant when ${ }^{<} 0.05$

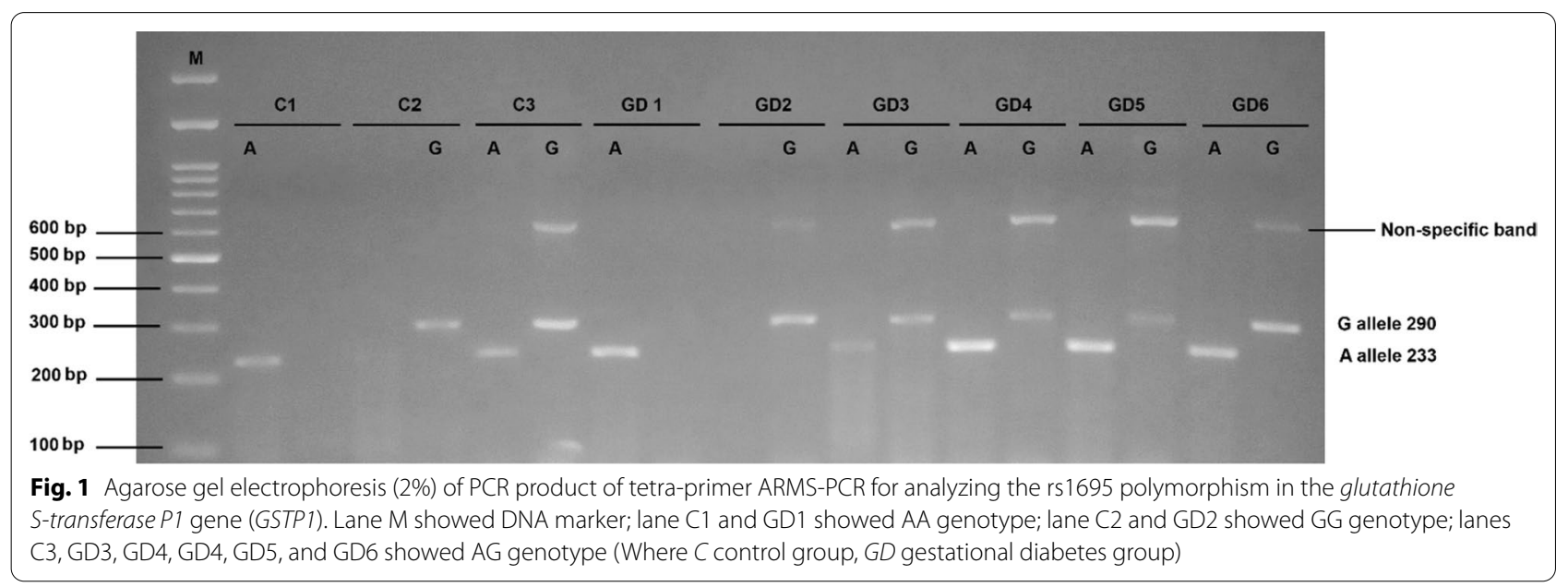

Table 5 Genotype frequencies of GSTP1 gene (rs1695) in the current study

\begin{tabular}{lllll}
\hline Genotype & Amino acid change & All subjects $(\boldsymbol{n}=\mathbf{1 4 0})$ & GDM group $(\boldsymbol{n}=\mathbf{7 0})$ & $\begin{array}{l}\text { Control } \\
\text { group } \\
(\boldsymbol{n}=\mathbf{7 0})\end{array}$ \\
\hline $\mathrm{A} / \mathrm{A}$ & lle/lle & $11(7.9 \%)$ & $6(8.6 \%)$ & $5(7.1 \%)$ \\
$\mathrm{A} / \mathrm{G}$ & lle/Nal & $120(85.7 \%)$ & $61(87.1 \%)$ & $59(84.3 \%)$ \\
$\mathrm{G} / \mathrm{G}$ & $\mathrm{Val} / \mathrm{Val}$ & $9(6.4 \%)$ & $3(4.3 \%)$ & $6(8.6 \%)$ \\
\hline
\end{tabular}

The data was expressed as frequency and percentage

GDM gestational diabetes mellitus

risk of GDM when compared with the AA genotype (OR 1.22, 95\% CI 0.354-4.195, $P=0.753$ ). The recessive model did not display any significant risk of GDM compared with the A/A-A/G genotype (OR 2.09, 95\% CI $0.502-8.73, P=0.301)$. Similarly, the overdominant did not show any significant risk of GDM compared with the A/A-G/G genotype (OR 0.791, 95\% CI 0.306-2.05, $P=0.629$ ). 
Table 6 Fisher exact test for Hardy-Weinberg equilibrium in the current study

\begin{tabular}{lcc}
\hline GDM group $(\boldsymbol{n}=\mathbf{7 0})$ & $\begin{array}{l}\text { Control } \\
\text { group } \\
(\boldsymbol{n}=\mathbf{7 0})\end{array}$ \\
\hline HWE & $X^{2}=38.96$ & $X^{2}=32.95$ \\
$P$ value & $P<0.001$ * & $P<0.001^{*}$ \\
\hline GDM gestational diabetes mellitus, $X^{2}$ chi-square test, HWE Hardy-Weignberg \\
equilibrium
\end{tabular}

\section{Correlation between insulin resistance, lipid profile, and GSTP1 (rs 1695) SNP}

The association between lipid profile, insulin resistance, and GSTP1 gene (rs1695) SNP in the population under the study was presented in Table 8 . In all these study cases, no significant difference was found between the lipid profile, insulin resistance, and GSTP1 (rs1695) SNP.

\section{Genotype analysis of GHRL gene}

The genetic polymorphisms in the GHRL gene were analyzed and the genotypes were shown in Fig. 2. The frequencies of genotype of the GHRL (rs696217) between pregnant women diagnosed with gestational diabetes and healthy pregnant women were listed in Table 9. In the distribution of genotypes, there were no significant differences between groups.

\section{Discussion}

Gestational diabetes mellitus is the most prevalent disease in pregnant women worldwide. It is a complex metabolic state that is distinguished by insulin resistance [18]. In this study, we assessed a possible association between glutathione S-transferase P1 Ile105Val SNP (rs1695) as well as ghrelin Leu72Met SNP (rs696217) and patient risk of gestational diabetes among Egyptian women.

Our results showed that insulin resistance was related to women with GDM. Previous studies have reported that women with GDM with high insulin resistance had a higher blood glucose level in either an early or a late pregnancy than women with GDM with less insulin resistance [19].

Hyperlipidemia is one of the metabolic disturbances that have been diagnosed in women with GDM. Insulin resistance and estrogen stimulation lead to an increase in plasma lipid levels throughout pregnancy [20]. The levels of total cholesterol, triglycerides, LDL-cholesterol, and

Table 7 Association between genotypes of GSTP1 with response status in the current study

\begin{tabular}{|c|c|c|c|c|c|}
\hline Model & Genotype & $\operatorname{GDM}(n=70)$ & Control $(n=70)$ & OR $(95 \% \mathrm{Cl})$ & $P$ \\
\hline \multirow[t]{3}{*}{ Codominant } & $\mathrm{A} / \mathrm{A}$ & $6(8.6 \%)$ & $5(7.1 \%)$ & $2.40(0.38-14.88)$ & 0.342 \\
\hline & $A / G$ & $61(87.1 \%)$ & $59(84.3 \%)$ & $2.07(0.494-8.65)$ & 0.31 \\
\hline & $\mathrm{G} / \mathrm{G}$ & $3(4.3 \%)$ & $6(8.6 \%)$ & 1 & \\
\hline \multirow[t]{2}{*}{ Dominant } & $\mathrm{A} / \mathrm{A}$ & $6(8.6 \%)$ & $5(7.1 \%)$ & $1.22(0.354-4.195)$ & 0.753 \\
\hline & $A / G-G / G$ & 64 (91.4\%) & 5 (92.9\%) & - & \\
\hline \multirow[t]{2}{*}{ Recessive } & $\mathrm{A} / \mathrm{A}-\mathrm{A} / \mathrm{G}$ & 67 (95.7\%) & $64(91.4 \%)$ & $2.09(0.502-8.73)$ & 0.301 \\
\hline & $\mathrm{G} / \mathrm{G}$ & $3(4.3 \%)$ & $6(8.6 \%)$ & - & \\
\hline \multirow[t]{2}{*}{ Overdominant } & $\mathrm{A} / \mathrm{A}-\mathrm{G} / \mathrm{G}$ & $9(12.9 \%)$ & $11(15.7 \%)$ & $0.791(0.306-2.05)$ & 0.629 \\
\hline & $\mathrm{A} / \mathrm{G}$ & $61(87.1 \%)$ & $59(84.3 \%)$ & - & \\
\hline
\end{tabular}

The data was presented as percentage and frequency

GDM gestational diabetes mellitus, OR odds ratio, $95 \% \mathrm{Cl} 95 \%$ confidence interval for the difference among the means for both groups. $P$ is significant when $<0.005$

Table 8 Correlation between insulin resistance, lipid profile and GSTP1 (rs1695) SNP in the current study

\begin{tabular}{lllll}
\hline Parameters & Genotype AA $(\boldsymbol{n}=\mathbf{1 1})$ & Genotype AG $(\boldsymbol{n}=\mathbf{1 2 0})$ & Genotype GG $(\boldsymbol{n}=\mathbf{9})$ & $\boldsymbol{P}$ \\
\hline Insulin resistance & $23.39(16.19-29.0)$ & $24.08(17.68-28.89)$ & $30.04(20.60-35.18)$ & $1180.91 \pm 16.89$ \\
Total lipids $(\mathrm{mg} / \mathrm{dL})$ & $1196.01 \pm 229.76$ & $1138.91 \pm 170.10$ & $228.29 \pm 63.70$ \\
Total cholesterol $(\mathrm{mg} / \mathrm{dL})$ & $245.01 \pm 25.54$ & $227.59 \pm 34.26$ & $329.93 \pm 55.77$ & 0.697 \\
Triglycerides $(\mathrm{mg} / \mathrm{dL})$ & $321.93 \pm 70.07$ & $295.51 \pm 51.69$ & $24.25 \pm 12.83$ & 0.510 \\
$\mathrm{HDL}$-cholesterol $(\mathrm{mg} / \mathrm{dL})$ & $27.22 \pm 2.66$ & $25.24 \pm 6.01$ & $135.91 \pm 48.77$ & 0.312 \\
$\mathrm{LDL}$-cholesterol $(\mathrm{mg} / \mathrm{dL})$ & $151.29 \pm 27.96$ & $141.39 \pm 32.78$ & $55.79 \pm 11.44$ & 0.717 \\
VLDL-cholesterol $(\mathrm{mg} / \mathrm{dL})$ & $63.87 \pm 14.37$ & $59.83 \pm 11.26$ & 0.583 \\
\hline
\end{tabular}

The data was presented as median and interquartile range or mean and standard deviation

95\% Cl 95\% confidence interval for the difference between the means for both groups. $P$ is significant when $` 0.05$ 


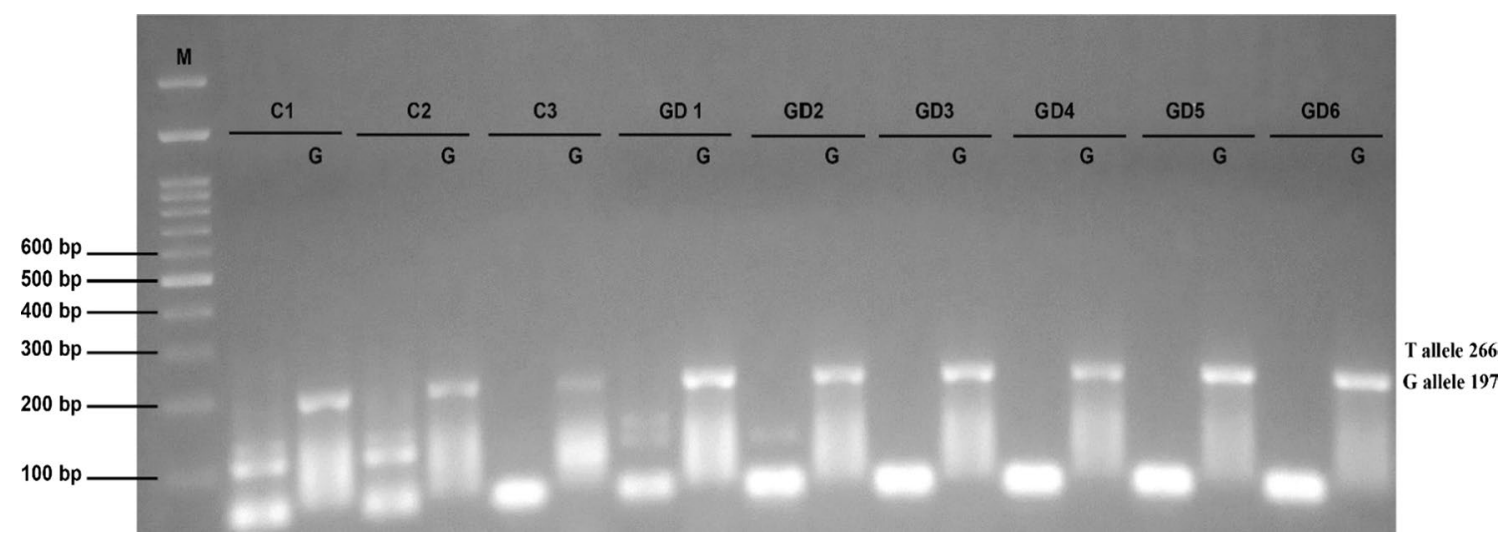

Fig. 2 Agarose gel electrophoresis (2\%) of PCR product of tetra-primer ARMS-PCR for analyzing the rs696217 polymorphism in the GHRL gene. Lane M showed DNA marker; lane C1, C2, and C3 showed GG genotype; lanes GD1, GD2, GD3, GD4, GD4, GD5, and GD6 showed GG genotype (Where C control group, GD gestational diabetes group)

Table 9 Genotype frequencies of GHRL gene (rs696217) in the current study

\begin{tabular}{lllll}
\hline Genotype & Amino acid change & All subjects $(\boldsymbol{n}=\mathbf{1 4 0})$ & GDM group $(\boldsymbol{n}=\mathbf{7 0})$ & $\begin{array}{l}\text { Control } \\
\text { group } \\
(\boldsymbol{n}=\mathbf{7 0})\end{array}$ \\
\hline $\mathrm{G} / \mathrm{G}$ & & & $70(100 \%)$ \\
$\mathrm{G} / \mathrm{T}$ & Leu/Leu & $100(100 \%)$ & $70(100 \%)$ & $0(0 \%)$ \\
$\mathrm{T} / \mathrm{T}$ & Leu/Met & $0(0 \%)$ & $0(0 \%)$ & $0(0 \%)$ \\
\hline
\end{tabular}

The data was expressed as frequency and percentage

GDM gestational diabetes mellitus

VLDL-cholesterol were elevated in GDM due to increasing hyperphagia (an abnormally excessive appetite for the consumption of food-related to hypothalamic damage), progesterone, lipogenesis, and fat storage in the first twothirds of gestation [21].

Our results showed that total lipids, total cholesterol, triglycerides, LDL-cholesterol, VLDL-cholesterol levels increased and HDL-cholesterol levels decreased in women with GDM. Previous studies revealed that GDM changes cholesterol metabolism where total cholesterol levels were significantly elevated in GDM compared with normal pregnant women. Women with GDM had high levels of LDL cholesterol [22]. Both VLDL cholesterol and triglycerides were significantly elevated in GDM than in normal pregnant women. Shen et al. [23] reported that the levels of lipids increased steadily throughout pregnancy and reached a peak before delivery, but the levels of HDL cholesterol increased from the 1st to 2nd trimester accompanied by a little decrease in the 3rd trimester. However, hyperlipidemia may be a physiological or pathological condition, so it is difficult to determine it. In addition, there are no standards for measuring maternal lipid levels due to the heterogeneity in meta-analysis and the region of the world's population [24].

Gene polymorphisms change the gene expression, structure, and quantity of the products that affect gene function. This is the first study to demonstrate that the frequencies of genotype and the allele of rs1695 in GSTP1 were not associated with gestational diabetes in Egyptian women. The dispersal of genotypes was in alignment with Hardy-Weinberg equilibrium. Similar to other studies, in a Chinese population, GSTP1 IIe105Val polymorphisms did not have an impact on the risk of gestational diabetes mellitus [25]. Li et al. [26] found that the GSTP1 IIe105Val polymorphism was not associated with an elevated risk of gestational diabetes mellitus in a Chinese population. Yalin et al. [27] found that the GSTP1 polymorphism was suggested to have no effect on the development of diabetes mellitus in Turkish patients. There was no significant association between the GSTP1 IIe105Val polymorphism and developing type 2 diabetes mellitus in overall studies [28].

Zhang et al. [29] revealed that the GSTP1 heterozygous genotype is significantly associated with type 2 diabetes mellitus in the north Indian population. There was an 
association between the GSTP1 Ile105Val gene polymorphism in overweight and obese patients for more than 60 years in southern Brazil [30]. Our study showed that there was no significant difference between the lipid profile, insulin resistance, and GSTP1 (rs1695) SNP in women with gestational diabetes. The current study is in agreement with Amer et al. [31], who demonstrated that there was no significant influence of different genotypes of the GSTP1 gene on lipid profile in the Egyptian population.

Ghrelin is a key factor in the hypothalamic melanocortin system, which is involved in various bioactivities [32]. The present study revealed that the GHRL gene (G/T rs696217) polymorphism was not significantly associated with gestational diabetes in Egyptian women. Rocha et al. revealed that the Gln90Leu polymorphism of the preproghrelin gene was not correlated with gestational diabetes in the Euro-Brazilian population [33]. Kim et al. [34] found that the Leu72Met polymorphism of the preproghrelin gene is not related to type 2 diabetes mellitus or to its complications. Joatar et al. [35] found that the Leu72Met polymorphism of GHRL was not associated with T2DM, IR, or serum ghrelin levels in a Saudi population. No associations were found between genotypes and ghrelin serum levels in a Mexican population [36]. Bai et al. [37] found that the genotype and allele frequencies of GHRL gene polymorphisms in participants with obesity showed no significant difference compared to those in nonobese controls in Chinese subjects.

In disagreement with other studies, the Leu72Met polymorphism of the GHRL gene had an impact on type 2 diabetes in the Finnish population [38]. In the Caucasian population, there was an association between the Leu72Met polymorphism of the GHRL gene and a decreased risk of type 2 diabetes [39]. A Ghrelin Arg51Gln polymorphism was detected in the Helsinki population with type 2 diabetes [40]. The Leu72Met polymorphism contributes to the development of obesity in the Swedish population [41].

\section{Conclusions}

Worldwide, pregnant women are at high risk of developing gestational diabetes. The study of risk factors will decrease the incidence. Therefore, this study aimed to evaluate the correlation between gene polymorphism in GSTP1 and ghrelin in the development of gestational diabetes. It was found that glutathione S-transferase P1 IIe105Val (A/G rs1695) and ghrelin Leu72Met SNP (G/T rs696217) were not correlated with gestational diabetes mellitus in Egyptian women.
Abbreviations

GDM: Gestational diabetes; GSTP1: Glutathione S-transferase P1; GHRL: Ghrelin; HCS: Human chorionic somatomammotropin; GSTs: Glutathione S-transferases; GHSR: Growth hormone secretagogue receptor; SNPs: Singlenucleotide polymorphisms; T-ARMS-PCR: Tetra-primer amplification refractory mutation system polymerase chain reaction.

\section{Acknowledgments}

We express gratitude to all of the Obstetrics and Gynecology Department, Faculty of Medicine, Mansoura University for making it possible to collect maternal blood samples.

\section{Authors' contributions}

MMM contributed to the methodology, analysis, investigation, and writing original manuscript. FE contributed to the methodology, acquisition, analysis, and investigation. AE contributed to the methodology, analysis and investigation. AAE contributed to interpretation of data, supervision, reviewing, and editing of the manuscript. AFA contributed to designing the work, supervision, reviewing, and editing of the manuscript. All authors have read and approved the manuscript for publication.

\section{Funding}

None.

Availability of data and materials

The authors can confirm that all relevant data are included in the manuscript.

\section{Declarations}

\section{Ethics approval and consent to participate}

This study was approved by ethical standards of the Institutional Research Board, Faculty of Medicine, Mansoura University. The patient provided written informed consent.

\section{Consent for publication}

Not applicable.

\section{Competing interests}

The authors declare that they have no competing interests.

\section{Author details}

${ }^{1}$ Biochemistry Division, Department of Chemistry, Faculty of Science, Mansoura University, Mansoura, Egypt. ${ }^{2}$ Genetic Unit, Department of Pediatrics, Faculty of Medicine, Mansoura University, Mansoura, Egypt. ${ }^{3}$ Department of Obstetrics and Gynecology, Faculty of Medicine, Mansoura University, Mansoura, Egypt.

Received: 23 June 2021 Accepted: 12 November 2021

Published online: 01 February 2022

\section{References}

1. Shen Y, Jia Y, Zhou J et al (2020) Association of gestational diabetes mellitus with adverse pregnancy outcomes: our experience and meta-analysis. Int J Diabetes Dev Ctries 1-14

2. HAPO Study Cooperative Research Group, Metzger BE, Lowe LP et al (2008) Hyperglycemia and adverse pregnancy outcomes. N Engl J Med 358(19):1991-2002

3. Park S, Kim M, Baik S-H et al (2013) Gestational diabetes is associated with high energy and saturated fat intakes and with low plasma visfatin and adiponectin levels independent of prepregnancy BMI. Eur J Clin Nutr 67(2):196-201

4. Ngala RA, Fondjo LA, Gmagna P, Ghartey FN, Awe MA (2017) Placental peptides metabolism and maternal factors as predictors of risk of gestational diabetes in pregnant women. A case-control study. PLOS ONE 12(7):1-15

5. Herrera E, Desoye G (2016) Maternal and fetal lipid metabolism under normal and gestational diabetic conditions. Horm Mol Biol Clin Investig 26(2):109-127 
6. Dong SC, Sha HH, Xu XY et al (2018) Glutathione S-transferase pi: a potential role in antitumor therapy. Drug Des Dev Ther 12:3535-3547

7. Yadav P, Banerjee A, Boruah N et al (2020) Glutathione S-transferasesP1 AA (105lle) allele increases oral cancer risk, interacts strongly with c-Jun Kinase and weakly detoxifies areca-nut metabolites. Sci Rep 10(1):6032-6043

8. Nissar S, Sameer A, Rasool R, Chowdri N, Rashid FJJCM (2017) Glutathione $S$ transferases: biochemistry, polymorphism and role in colorectal carcinogenesis. J Carcinog Mutagen 8(2):287-296

9. Bednarek MA, Feighner SD, Pong SS et al (2000) Structure-function studies on the new growth hormone-releasing peptide, ghrelin: minimal sequence of ghrelin necessary for activation of growth hormone secretagogue receptor 1a. J Med Chem 43(23):4370-4376

10. Zhang X, Zhai L, Rong C, Qin X, Li S (2015) Association of ghrelin gene polymorphisms and serum ghrelin levels with the risk of hepatitis $B$ virusrelated liver diseases in a Chinese population. PLOS ONE 10(11):1-14

11. Zallar LJ, Tunstall BJ, Richie CT et al (2019) Development and initial characterization of a novel ghrelin receptor CRISPR/Cas9 knockout wistar rat model. Int J Obes (Lond) 43(2):344-354

12. Sovetkina A, Nadir R, Fung JNM, Nadjarpour A, Beddoe B (2020) The physiological role of ghrelin in the regulation of energy and glucose homeostasis. Cureus 12(5):1-8

13. Zöllner N, Kirsch K (1962) Colorimetric method for determination of total lipids. J Exp Med 135:545-561

14. Richmond W (1973) Preparation and properties of a cholesterol oxidase from Nocardia sp. and its application to the enzymatic assay of total cholesterol in serum. Clin Chem 19(12):1350-1356

15. Fossati P, Prencipe $L$ (1982) Serum triglycerides determined colorimetrically with an enzyme that produces hydrogen peroxide. Clin Chem 28(10):2077-2080

16. Burstein M, Scholnick HR, Morfin R (1970) Rapid method for the isolation of lipoproteins from human serum by precipitation with polyanions. J Lipid Res 11(6):583-595

17. Friedewald WT, Levy RI, Fredrickson D (1972) Estimation of the concentration of low-density lipoprotein cholesterol in plasma, without use of the preparative ultracentrifuge. Clin Chem 18(6):499-502

18. Grupe K, Asuaje Pfeifer M, Dannehl F et al (2020) Metabolic changes during pregnancy in glucose-intolerant NZO mice: a polygenic model with prediabetic metabolism. Physiol Rep 8(9):1-13

19. Benhalima K, Van Crombrugge P, Moyson C et al (2019) Characteristics and pregnancy outcomes across gestational diabetes mellitus subtypes based on insulin resistance. Diabetologia 62(11):2118-2128

20. Ryckman KK, Spracklen CN, Smith CJ, Robinson JG, Saftlas AF (2015) Maternal lipid levels during pregnancy and gestational diabetes: a systematic review and meta-analysis. BJOG 122(5):643-651

21. Herrera EJ (2000) Metabolic adaptations in pregnancy and their implications for the availability of substrates to the fetus. Eur J Clin Nutr 54(1):S47-S51

22. Wang J, Li Z, Lin L (2019) Maternal lipid profiles in women with and without gestational diabetes mellitus. J Med 98(16):1-6

23. Shen H, Liu X, Chen Y, He B, Cheng W (2016) Associations of lipid levels during gestation with hypertensive disorders of pregnancy and gestational diabetes mellitus: a prospective longitudinal cohort study. BMJ Open 6(12):1-7

24. Herrera E, Ortega-Senovilla H (2014) Lipid metabolism during pregnancy and its implications for fetal growth. Curr Pharm Biotechnol 15(1):24-31

25. Qiu YH, Xu YL, Zhang WH (2016) Effect of GSTM1, GSTT1, and GSTP1 Ile105Val polymorphisms on susceptiblity to gestational diabetes mellitus. Genet Mol Res 15(2):1-7

26. Li Y, Li S, Zhai Q et al (2015) Association of GSTs polymorphisms with risk of gestational diabetes mellitus. Int J Clin Exp Pathol 8(11):15191-15197

27. Yalin S, Hatungil R, Tamer L et al (2007) Glutathione S-transferase gene polymorphisms in Turkish patients with diabetes mellitus. Cell Biochem Funct 25(5):509-513

28. Saadat M (2017) Evaluation of glutathione S-transferase P1 (GSTP1) Ile105Val polymorphism and susceptibility to type 2 diabetes mellitus, a meta-analysis. EXCLI J 16:1188-1197

29. Bid HK, Konwar R, Saxena M, Chaudhari P, Agrawal CG, Banerjee M (2010) Association of glutathione S-transferase (GSTM1, T1 and P1) gene polymorphisms with type 2 diabetes mellitus in north Indian population. J Postgrad Med 56(3):176-181
30. Chielle EO, Fortuna PC, Maziero JS (2016) Association between the glutathione S-transferase P1 (GSTP1) Ile105Val gene polymorphism in obese and overweight patients over 60 years. J Bras Patol Med Lab 52(4):211-216

31. Amer MA, Ghattas MH, Abo-Elmatty DM, Abou-El-Ela SH (2012) Evaluation of glutathione S-transferase $\mathrm{P} 1$ genetic variants affecting type-2 diabetes susceptibility and glycemic control. Arch Med Sci 8(4):631-636

32. Kim JD, Leyva S, Diano S (2014) Hormonal regulation of the hypothalamic melanocortin system. Front Physiol 5:480-487

33. Rocha RA, Frigeri HR, Santos-Weiss IC et al (2014) Preproghrelin polymorphism Q90L (rs4684677) in gestational diabetes. Arq Bras Endocrinol Metabol 58(1):83-84

34. Kim S-Y, Jo D-S, Hwang PH et al (2006) Preproghrelin Leu72Met polymorphism is not associated with type 2 diabetes mellitus. Metaboilsm 55(3):366-370

35. Joatar FE, Al Qarni AA, Ali ME et al (2017) Leu72Met and other intronic polymorphisms in the GHRL and GHSR genes are not associated with Type 2 diabetes mellitus, insulin resistance, or serum ghrelin levels in a saudi population. Endocrinol Metab 32(3):360-369

36. Rivera-León EA, Llamas-Covarrubias MA, Sánchez-Enríquez S, MartínezLópez E, González-Hita M, Llamas-Covarrubias IMJBED (2020) Leu72Met polymorphism of GHRL gene decreases susceptibility to type 2 diabetes mellitus in a Mexican population. BMC Endocr Disord 20(1):1-5

37. Bai R, Liu Y, Zhao C, Gao J, Liu R (2021) Distribution and effect of ghrelin genotype on plasma lipid and apolipoprotein profiles in obese and nonobese Chinese subjects. Hormones (Athens) 20(3):527-535

38. Mager U, Lindi V, Lindstrom J et al (2006) Association of the Leu72Met polymorphism of the ghrelin gene with the risk of Type 2 diabetes in subjects with impaired glucose tolerance in the Finnish Diabetes Prevention Study. Diabet Med 23(6):685-689

39. Berthold HK, Giannakidou E, Krone W, Mantzoros CS, Gouni-Berthold I (2009) The Leu72Met polymorphism of the ghrelin gene is associated with a decreased risk for type 2 diabetes. Clin Chim Acta 399(1-2):112-116

40. Poykko S, Ukkola O, Kauma H, Savolainen MJ, Kesaniemi YA (2003) Ghrelin Arg51GIn mutation is a risk factor for Type 2 diabetes and hypertension in a random sample of middle-aged subjects. Diabetologia 46(4):455-458

41. Ukkola O, Ravussin E, Jacobson P et al (2001) Mutations in the preproghrelin/ghrelin gene associated with obesity in humans. J Clin Endocrinol Metab 86(8):3996-3999

\section{Publisher's Note}

Springer Nature remains neutral with regard to jurisdictional claims in published maps and institutional affiliations.

\section{Submit your manuscript to a SpringerOpen ${ }^{\circ}$ journal and benefit from:}

- Convenient online submission

- Rigorous peer review

- Open access: articles freely available online

- High visibility within the field

- Retaining the copyright to your article

Submit your next manuscript at $\mathbf{s p r i n g e r o p e n . c o m ~}$ 